Running head: Temporal Dynamics of Corporate Venturing in Family Business

\title{
CORPORATE VENTURING IN FAMILY BUSINESS: A DEVELOPMENTAL APPROACH OF THE ENTERPRISING FAMILY
}

\section{TOMMASO MINOLA,,${ }^{1,2}$ MARA BRUMANA, ${ }^{1,2}$ GIOVANNA CAMPOPIANO, ${ }^{3}$ ROBERT PAUL GARRETT, ${ }^{4 *}$ and LUCIO CASSIA ${ }^{1,2}$}

${ }^{1}$ Center for Young and Family Enterprise (CYFE), University of Bergamo, Bergamo, Italy

${ }^{2}$ Department of Management, Information and Production Engineering, University of Bergamo, Bergamo, Italy

${ }^{3}$ Chair of Business Administration \& Family Entrepreneurship, Witten Institute for Family

Business (WIFU), University of Witten/Herdecke, Witten, Germany

${ }^{4}$ College of Business, University of Louisville, Louisville, Kentucky, U.S.A.

Keywords: enterprising family; corporate venturing; family development theory; family business developmental model

*Correspondence to: Robert Paul Garrett, College of Business W201, University of Louisville, Louisville, KY 40292, U.S.A. E -mail: robert.garrett@louisville.edu.

Tommaso Minola

Director at the Center for Young and Family Enterprise (CYFE)

Assistant Professor at the Department of Management, Information and Production

Engineering, University of Bergamo, Italy

via Pasubio $7 b$ - 24044 Dalmine (BG) - Italy

E-mail: tommaso.minola@unibg.it

Phone: +39 (0)352052025

Mara Brumana

Research fellow at the Center for Young and Family Enterprise (CYFE)

Department of Management, Information and Production Engineering, University of

Bergamo, Italy

via Pasubio $7 b$ - 24044 Dalmine (BG) - Italy

E-mail: mara.brumana@,unibg.it

Phone: +39 (0)352052025

Giovanna Campopiano

Assistant Professor at the Chair of Business Administration \& Family Entrepreneurship

Witten Institute for Family Business, University of Witten/Herdecke, Germany

E-mail: giovanna.campopiano@uni-wh.de

Phone: +49 (0)2302 926541

This article has been accepted for publication and undergone full peer review but has not been through the copyediting, typesetting, pagination and proofreading process which may lead to differences between this version and the Version of Record. Please cite this article as doi: $10.1002 /$ sej.1236 
Robert Paul Garrett (*)

Assistant Professor of Entrepreneurship

University of Louisville, College of Business

Louisville, KY 40292, USA

E-mail: robert.garrett@louisville.edu

Phone: $\underline{502-852-4790}$

Fax: $\underline{502-852-1752}$

Lucio Cassia

Chairman at the Center for Young and Family Enterprise (CYFE)

Full Professor at the Department of Management, Information and Production Engineering,

University of Bergamo, Italy

via Pasubio $7 b$ - 24044 Dalmine (BG) - Italy

E-mail: lucio.cassia@unibg.it

Phone: +39 (0)352052350

\section{Research summary}

This conceptual article discusses when and why family firms are motivated to engage in entrepreneurial activities. Drawing on family development theory, we offer midrange reasoning about the impact of enterprising family dynamics-such as the birth of a child or children leaving home-on the motivation for corporate venturing and its changes over time. Moreover, our model also accounts for the contingent effect of ownership and business developmental dimensions. Finally, we predict that motivation for corporate venturing can, in turn, spur the development of the enterprising family.

\section{Managerial summary}

Overcoming the idea that family firms are either very or minimally entrepreneurial, we focus on the enterprising family and consider its development to explain the motivation toward corporate venturing. We look at the evolution of the roles and norms of family members over time and predict that motivation for venturing increases with family growth until the moment in which a succession takes place and the younger generation receives the baton. We also consider how changes in the ownership structure and business growth influence the relationship between family development and motivation for venturing. The latter, in turn, can trigger the development of the enterprising family itself, with its structure and norms. Our work, in sum, depicts the enterprising family as a springboard for repeated acts of entrepreneurship across generations. Copyright (C) 2016 Strategic Management Society. 


\section{INTRODUCTION}

Corporate venturing $(\mathrm{CV})$ is a strategic entrepreneurial activity that results in the creation of a new business within an existing corporate entity (Sharma and Chrisman, 1999). According to the literature, companies engage in $\mathrm{CV}$ activities for various reasons: to build an innovative capability as the basis for making the firm more innovative and change oriented; to gain greater value from existing competencies and expand the firm's scope into new areas of possible strategic importance; and to generate quick financial returns (Miles and Covin, 2002; Morris, Kuratko, and Covin, 2010). When existing firms behave entrepreneurially, they are often able to gain competitive advantage as they improve their flexibility, adaptability, speedto-market, and learning processes (Covin and Miles, 1999; Sharma and Chrisman, 1999; Zahra and Covin, 1995).

$\mathrm{CV}$ activities are especially relevant to family firms. Family firms are defined as businesses 'governed and/or managed with the intention to shape and pursue the vision of the business held by a dominant coalition controlled by members of the same family or a small number of families in a manner that is potentially sustainable across generations of the family or families' (Chua, Chrisman, and Sharma, 1999: 25). Family businesses have attracted the attention of entrepreneurship scholars because of their family-influenced resources, behaviors, and preferences that lead to idiosyncratic firm strategies and distinctive governance processes (Lumpkin, Steier, and Wright, 2011; Nordqvist and Melin, 2010). Continuous entrepreneurial activities are needed to sustain and renew family firms in changing competitive environments (Cruz and Nordqvist, 2012). Among the different types of corporate entrepreneurship, $\mathrm{CV}$ is of particular interest to family firms. Indeed, the

creation of new businesses within the existing corporate entity is a way to spur transgenerational entrepreneurship, ensure transgenerational wealth creation, and warrant persistent involvement of multiple generations in the business (Habbershon and Pistrui, 2002; 
Marchisio et al., 2010). With CV, for instance, family firms can answer the financial and employment needs of a growing family and help ensure intergenerational survival of the family business (Greidanus, 2011; Calabrò et al., 2016).

Although the previously cited literature has argued that CV can be particularly salient and interesting for family firms, there are contrasting opinions as to whether family firms are more or less likely to pursue entrepreneurial initiatives (Jaskiewicz, Combs, and Rau, 2015). On the one hand, some research asserts that family firms are known for lacking entrepreneurial behaviors (Bertrand and Schoar, 2006; Block, 2012; Bloom and Van Reenen, 2007), and there is also empirical evidence suggesting that they are less entrepreneurial than nonfamily firms (Rogoff and Heck, 2003). On the other hand, recent research advocates that some family firms do act entrepreneurially and are able to do so across multiple generations (Chirico et al., 2011; Jaskiewicz et al., 2015). So, while family firms are often described as low risk-takers, conservative, and not very entrepreneurial (e.g., Block, 2012; Gómez-Mejía et al., 2007), contrasting arguments claim that family firms are more likely than nonfamily firms to engage in entrepreneurial initiatives and to do so repeatedly over time (Miller and Le Breton-Miller, 2005; Nordqvist and Melin, 2010; Sieger et al., 2011).

The extant literature on CV in family businesses opens up several research opportunities to solve this puzzle. First, prior work in family business has been mostly anchored to the firm itself rather than the family (Rogoff and Heck, 2003). Thus, it is promising to examine how firm's embeddedness within a family affects entrepreneurial behavior (Aldrich and Cliff, 2003; Mattessich and Hill, 1976; Miller, Steier, and Le Breton-Miller, 2016). A shift in the level of analysis - from family business to enterprising family, namely a 'family that runs one or more businesses, and that has an intent to grow these businesses with the family as the foundation' (Nordqvist and Melin, 2010: 221; Habbershon and Pistrui, 2002)—is regarded as valuable in the entrepreneurship and family business literatures (Michael-Tsabari, Labaki, 
and Zachary, 2014). Second, exploring the motivation for venturing deserves further attention in the context of family firms. While existing research has focused mainly on family firms' ability to act entrepreneurially (e.g., Zahra, 2010), looking at the owners' willingness to engage in venturing initiatives is of strategic importance for the understanding of entrepreneurship in general (McKelvie et al., 2013), at the corporate level (Brundin, Patzelt, and Shepherd, 2008), and for family firms in particular (Greidanus, 2011; De Massis et al., 2014b). Although motivation does not necessarily lead to action, entrepreneurial motivation is an important precursor to entrepreneurial behavior (Shane, Locke, and Collins, 2003). Third, Michael-Tsabari et al. (2014) add that the role of motivation for venturing is even more important when considering the change over time of family business systems. Research on CV in family business, however, has maintained a static view of the family firm (Sciascia and Bettinelli, 2013; see also Sharma, Salvato, and Reay, 2014). It has studied risk preferences and entrepreneurial behaviors at points in time of the family business, rather than investigating how family firms evolve their entrepreneurial behaviors over time (De Massis et al., 2014a). In order to overcome this limitation, research on CV in family firms would benefit from a developmental perspective (Habbershon, 2006; Hoy, 2006; Rutherford, Muse, and Oswald, 2006). Our aim, therefore, is to contribute to the debate on CV in family firms by addressing the question of when and why enterprising families perceive corporate venturing as an attractive option.

Using a midrange theory approach (Merton, 1949; Pinder and Moore, 1978), we develop a conceptual model that blends family development theory (Rodgers, 1964; Rodgers and White, 1993) and the family business developmental model (Gersick et al., 1997). Through the former, we predict how the evolution of the family system-together with its roles, relationships, and tasks - determines norms and motives for (or against) entrepreneurial initiatives in family firms. Through the latter, we benefit from a consistent set of stages to 
analyze the evolution of the enterprising family. Moreover, the utilization of the family business developmental model highlights the influence of two additional dimensions that characterize a family firm besides family-i.e., ownership and business (Gersick et al., 1997; Tagiuri and Davis, 1996). Finally, our conceptual model proposes some development of the enterprising family as a result of motivation for CV activities.

Our article contributes to the literature in several ways. We add to entrepreneurship research by substantiating the importance and value of a family-related approach to $\mathrm{CV}$ (Marchisio et al., 2010; Rogoff and Heck, 2003). Enterprising families are, thus, revealed to be a distinctive context, as their progress and development can spur, or hamper, repeated acts of entrepreneurship over time (Jaskiewicz et al., 2015; Sieger et al., 2011). Moreover, we believe that corporate entrepreneurship scholars will be interested in our conceptualization of $\mathrm{CV}$ activities that allows for a firm's motivation toward entrepreneurial engagement to change over time. Overall, we provide a picture of the enterprising family and its motivation for (or against) $\mathrm{CV}$ that coevolve. Much of the corporate entrepreneurship literature assumes that a firm either is or is not entrepreneurial and that managerial intervention is often needed to promote entrepreneurship. Our approach allows not only for $\mathrm{CV}$ motivation to change over time, but for it to be a natural evolution of group dynamics, rather than circumstances manipulated by firm management. We also add to the family business literature by shedding light on the evolutionary nature of the family business system and extending Gersick et al.'s (1997) family business developmental model through family development theory (Rodgers, 1964; Rodgers and White, 1993). 


\section{THEORETICAL BACKGROUND}

In order to explore the evolution of enterprising family motivations to engage in $\mathrm{CV}$, our article is guided by family development theory (Rodgers, 1964; Rodgers and White, 1993; White, 1991) and Gersick et al.'s (1997) family business developmental model. Family development theory predicts 'changes in role expectations in the family over time as a function of changes in family membership, individual developmental needs, and direct societal expectations' (Chaulk, Johnson, and Bulcroft, 2003: 261). As such, it has been suggested as a promising perspective for the development of family-based studies in family business research (Jennings, Breitkreuz, and James, 2013; Paul et al., 2003). The theory is particularly suited for our purposes, as its major claim is that-based on normative expectations - the motivations and behaviors of family members evolve along with changes in family structure and family-related needs (Mattessich and Hill, 1987).

Developmental theorists have debated the very definition of family. The widest and most acknowledged definition is offered by White (1991: 7), who writes that 'A family is an intergenerational social group organized and governed by social norms regarding descent and affinity, reproduction, and the nurturant socialization of the young.' Consistent with this definition, the basic assumption of the theoretical perspective is that a family is composed of a married couple and one or more young children (Duvall, 1957; Paul et al., 2003). Each family member at a certain point in time occupies a given position-i.e., a 'location [...] in a system of social relationships' (Gross, Mason, and McEachern, 1958: 48) - and for each position, one can take on one or more roles, meaning 'part of a social position consisting of a more or less integrated or related subset of social norms which is distinguishable from other sets of norms forming the same position' (Bates, 1956: 314). For example, the position of husband is identified by a relational location in a bipolar social structure: a male connected 
by a marital relationship to a female. The role of the husband may change across culture and over time, together with its norms.

Another central tenet in family development theory is the concept of stage (Rodgers and White, 1993). As defined by Aldous (1978: 80), 'a stage is a division within the lifetime of a family that is distinctive enough from those that precede and follow it to constitute a separate period.' Family development is, hence, conceptualized as a process where the timing and sequencing of events affect how families function and move across stages (Stafford et al., 1999). Existing literature identifies different stage sequences, ranging from two to 24 family stages, with no particular sequence being considered as the 'jack of all trades' (Mattessich and Hill, 1987).

Transitions between stages manifest through events called stressors that induce normative changes (McCubbin et al., 1980; McCubbin and Patterson, 1983). For example, the birth of the first child (stressor) brings about a transition from husband and wife to husband-father and wife-mother (change in position and the related roles). Similarly, the stressor of children leaving home generates shifts in family roles and relationships, such as an improved child-parent relationship after the departure of a sibling (Laszloffy, 2002). The residue of tensions generated by the stressor, which remains unmanaged, generates family stress - e.g., transition to parenthood and problems of control and independence related to adolescence (McCubbin et al., 1980).

Families are resilient organizations that adapt to changes, both internally and externally generated. At every stage, therefore, the family system sets specific family developmental tasks and specific family goals (Cunningham, 1978; Mattessich and Hill, 1987; Rodgers, 1964). For example, physical maintenance is one of the main tasks of the first phase of family development and is oriented by the family-driven goal of nurturing children. In later stages of 
family development, the task of moral maintenance can be associated with the family-driven goal of launching youngsters in a professional career.

The family as a social group is governed by institutional norms, meaning 'a patterned or commonly held behavior expectation, a learned response, held in common by members of a group' (Bates, 1956: 314). Norms regulate a specific and coherent sector of social life and change over time together with the structure of the family (Rodgers and White, 1993). For instance, weekend gatherings or marital fidelity might be norms of the family institution as such. Norms are defined as cross-institutional when they are constituted from the merger of two or more norms from different institutions. Such norms regulate the development of one institution (e.g., the family) in conjunction and in harmony with other social institutions (e.g., the education system, labor market, and welfare systems) (Rodgers and White, 1993). A consequence of cross-institutional norms is the preference for family-related (family-first) tasks, such as the children's physical or moral maintenance, rather than business-related (business-first) tasks, such as the firm's growth and survival (Aldrich and Cliff, 2003; Stafford et al., 1999; Ward, 1987,) along the different stages of family development.

The most important advantage of family development theory is the multilevel nature of its predictions, incorporating individual family members, family relationships, the family group, and the institution of the family, collectively and individually guided by its specific and time-varying norms (Rodgers and White, 1993). In the context of our research, the family development theory allows us to build predictions about when and why CV may be an attractive option for a specific type of family — namely an enterprising family — as it pursues its primary goals of growth and survival (Gersick et al., 1997; Habbershon and Pistrui, 2002; Nordqvist and Melin, 2010). 
In order to characterize the development of the enterprising family, we refer to Gersick et al.'s (1997) family business developmental model. According to this framework, family firms are characterized by three developmental dimensions - family, ownership, and business - that interact and change over time. The family developmental dimension (FDD) describes the timing and sequencing of family events (e.g., entry of a new generation, authority transfer from parents to children, relationships between family members). It is articulated in four stages - i.e., young business family, entering the business, working together, and passing the baton - and has been used by family business scholars to describe the development of an enterprising family (Gersick et al., 1997). Accordingly, FDD represents the foundation of our conceptual model. Table 1 offers a summary of the tenets of the family development theory organized according to the four stages of Gersick et al.'s (1997) FDD.

Insert Table 1 about here

The ownership developmental dimension (ODD) describes instead the temporal evolution of a family firm's ownership structure from a controlling owner to a sibling partnership and a cousin consortium. Finally, the business developmental dimension (BDD) covers three stages — namely start-up, expansion/formalization, and maturity — and describes the development of the business over time with a particular focus on organizational change (growth and complexity of the organizational structure) (Gersick et al., 1997).

\section{THEORETICAL FRAMEWORK}

Our article builds upon the central tenets of family development theory and offers a midrange reasoning about the impact of enterprising family dynamics on the evolution of its motivation for CV. Theories of the midrange are 'theories that lie between the minor but necessary 
working hypotheses $[\ldots]$ and the all-inclusive systematic efforts to develop a unified theory that will explain all the observed uniformities of social behavior, social organization, and social change' (Merton, 1949: 39). While such a way of theorizing has intrinsic boundaries and limited scope in explaining social phenomena, it has also been considered a valuable and essential basis for the construction of more general theories (Pinder and Moore, 1978).

Our conceptual framework and the related propositions are based upon four main assumptions that define the scope of this study. First, although the literature suggests that two or more families could be involved in one business (Chua et al., 1999), we focus our attention on the development of a single nuclear family. In this way, we are able to isolate the mechanisms that cause the emergence of an enterprising family's motivations. For the same reason, the influence of nonfamily or external shareholders is not the direct focus of our theorization, as these individuals are not primarily driven by family norms.

Second, we refrain from considering family firms that are too large and have complex organizations. In such firms, the involvement of professionals and firm size are likely to make family norms less observable. Hence, our conceptual model initially assumes (Propositions 1a to 1d) that the evolution of FDD is observed when the family firm is positioned in the early stages of the other two developmental dimensions-ownership and business. A first attempt to extend our midrange predictions is provided in Propositions 2 and 3, where we discuss the effect of relaxing these assumptions.

Third, Gersick et al.'s (1997) model has been developed, building on and referring to the North American context. Although scholars have suggested that this model has international validity (e.g., Hoy, 2012), we do not assume necessarily that our midrange theory is universal and valid outside that specific context. Different geographical or cultural contexts and different institutional norms may, in fact, uniquely affect enterprising family development. Addressing this issue is beyond the scope of our effort. 
Fourth, although a married couple may have no children, (and, in fact, entrepreneurship literature shows growing interest in the phenomenon of co-preneurship (Fletcher, 2010)), when looking at FDD, we follow family development theory and consider that family development is driven by the presence of children within the family (Duvall, 1957).

Our conceptual model is depicted in Figure 1. Building on family development theory (Rodgers, 1964; Rodgers and White, 1993), we describe FDD as the pivotal dimension influencing the enterprising family's motivation for CV. Furthermore, we propose that both the ODD and the BDD interact with family development in its relationship with the enterprising family's motivation for CV. Finally, we advance that the motivation to pursue entrepreneurial initiatives can, in turn, affect the enterprising family's progression along its developmental dimension.

Insert Figure 1 about here

\section{Family development and motivation for corporate venturing}

Young business family stage

In this initial stage, the married couple has to deal with the creation of a marriage enterprise, where partners have to adjust to living as a married couple and caring about the balance between work and family. The birth of the first child (and subsequent children) activates the role of parenthood and the related rules as stipulated by norms from the institutions of marriage and family. The family unit has to be reorganized around children's needs, and parents are expected to follow stage-specific norms (Chaulk et al., 2003). Parents are subject to the provider norm with respect to the offspring, and they are concerned about their children's physical maintenance, security, and socialization. 
Given this concern for the future of children, preserving income is very important, because it allows for investments in schooling and sport or leisure. Parents behave for the benefit of their children and prepare them for subsequent family stages (Rodgers and White, 1993). As a result, at this stage, parents are eager to preserve business resources and not to invest them in high-risk initiatives such as CV (Chaulk et al., 2003; Sieger and Minola, forthcoming).

More generally, there is a lock-in tendency for the family, and family-first norms prevail (Rutherford et al., 2006). Given that parents struggle with both marital status and parenthood, they are focused mainly on the well-being of the family itself and, hence, concerned about its demands and survival needs rather than the growth and development of the family business (Mattessich and Hill, 1987). In other words, at this stage, parents are reluctant to risk business resources by investing in $\mathrm{CV}$ initiatives and are more eager to employ those resources to satisfy the basic needs of the family. Thus, we propose that:

Proposition la: At the young business family stage, enterprising family motivation for corporate venturing is low.

\section{Entering the business stage}

At this stage, parents become aware of their role as incumbents, while teen and young adult offspring keep growing in the enterprising family atmosphere. As the burden of parental responsibility (a salient feature of the previous stage) decreases when children age, parents are expected to increase their risk tolerance (Chaulk et al., 2003).

The norm parents are subject to shifts from provider to mentor, with the main tasks of training, developing, and strategically educating offspring in areas that could be relevant to their future and to the future of the enterprising family (Jaskiewicz et al., 2015). Given the mentoring norms that parents are expected to follow, $\mathrm{CV}$ can be particularly appreciated as a way to develop children's human capital, namely to enhance their business skills, selfconfidence, and leadership attitudes (Au et al., 2013; Greidanus, 2011; Miller et al., 2015). 
$\mathrm{CV}$ can also be perceived as a way for incumbents to evaluate children's skills and entrepreneurial propensity and, hence, to ease the succession process (Greidanus and Märk, 2012; Marchisio et al., 2010).

However, children at this stage are likely to be reluctant learners (Churchill and Hatten, 1997; Dyer, Nenque, and Hill, 2014). Children aim to assert their own autonomy pertaining to their individual careers and to resist their parents' desire for control (Davis and Tagiuri, 1989; Sieger and Minola, forthcoming). They start leaving home (children launching), establishing a career, and evaluating whether to join the family business. This generates tension and potential misalignment within the family, because children try to establish their own identities and, thus, claim freedom and autonomy (Davis and Tagiuri, 1989; McCubbin et al., 1980).

In sum, given the CV's value in accomplishing training and educational tasks, we expect an increase in the enterprising family's motivation for CV compared to the previous stage. This increase, though, will be modest because of children's requests for autonomy. Hence:

Proposition 1b: As the enterprising family moves from the young business family stage through the entering the business stage, motivation for corporate venturing increases.

Working together stage

In this phase, the family is often referred to as an empty nest (Duvall, 1957; Mattessich and Hill, 1987) because children have left home. They have also disclosed whether they want to work within the family business. The burden of parental responsibility related to children aging continues to decrease (Chaulk et al., 2003), and offspring are likely to be given an autonomous area of responsibility within the family firm (Davis and Tagiuri, 1989). Moreover, new members - both in-laws and grandchildren — contribute to extend the family. 
While parents still follow the norm of mentoring, children are now engaged learners. Accordingly, the parent-child relationship is relatively harmonious at this life stage: 'the son wants to learn and grow in competence at precisely the time when the father wants to teach and help the younger generation to develop' (Davis and Tagiuri, 1989: 54). In this situation, so-called entrepreneurial bridging-namely 'a period of working together side-by-side wherein the older generation manages operations and gives the younger generation the opportunity to apply its strategic education' (Jaskiewicz et al., 2015: 30) —is more likely to occur. In other words, children willingly embrace $\mathrm{CV}$ as a learning opportunity. Entrepreneurial bridging may, thus, motivate the enterprising family to engage in multiple acts of entrepreneurship (e.g., CV) in a short time-_entrepreneurial leaps' (Jaskiewicz et al., 2015).

Moreover, at this stage, family incumbents aim to integrate new family members - both offspring and in-laws - into the management of the family firm and to avoid sibling buyouts. In doing so, they engage in a process called strategic succession (Jaskiewicz et al., 2015). The core business may no longer be adequate to the size of the enterprising family and to the satisfaction of its needs (De Massis et al., 2014a). Accordingly, family members may perceive $\mathrm{CV}$ as an appropriate means to grow the business and to answer family members' requests (Greidanus, 2011). Together with purely economic motivations, the family business also represents an opportunity for a growing number of family members to obtain reputation, prestige, and identification within the enterprising family (Zellweger et al., 2013). This promotes in each member of the enterprising family a pro-organizational and collectivistic behavior — stewardship mind-set (Davis, Schoorman, and Donaldson, 1997) —and, hence, leads to an increase in motivation for entrepreneurial initiatives (Corbetta and Salvato, 2004; Zahra, 2003). In fact, families highly committed to the firm are more likely to reduce their claims for dividends and payoffs from the core business, thus favoring the accumulation of 
resources needed to launch different entrepreneurial ventures (Eddleston and Kellermanns, 2007; Kellermanns and Eddleston, 2006).

Given the normative alignment that parents, children, and other family members reach at this stage, we speculate that:

Proposition 1c: As the enterprising family moves from the entering the business stage to the working together stage, motivation for corporate venturing increases.

\section{Passing the baton stage}

In the final stage of family development, parents are at the end of their careers, while children increasingly take on caregiving responsibilities of both the business (e.g., 'the father assumes the chairmanship position and turns over operational responsibilities to the son' (Davis and Tagiuri, 1989: 73)) and of older family members (physical maintenance) (Chaulk et al., 2003).

This last stage of family development has some peculiar characteristics. First, older individuals are generally more conservative and less entrepreneurial than younger ones (Minola, Criaco and Obschonka, 2016), and most of their attention is focused on the successful transition of currently operating businesses to the new generation, rather than on the creation of new businesses (Davis and Tagiuri, 1989). Second, the provider norm that characterizes the first stage of family development returns to be salient for family principals at this stage. On the one hand, the new generation's family members find themselves subject to a sort of reciprocal provider norm toward the older generation: children are expected to care for parents in their old age, and subsidies to the family (e.g., parents' institutionalization) distract resources and attention from the business (Aldrich and Cliff, 2003). On the other hand, they anticipate the forthcoming norm of being providers toward their own children. All this might recall the family-first norms of the young family business stage and cause a weakening in the overall motivation for CV. Third, disputes over the goals of the business- 
e.g., tensions between family and commercial norms - are particularly likely to emerge when the enterprising family approaches succession (Kotlar and De Massis, 2013). Thus, the normative alignment among family members is jeopardized.

Since the arguments for an overall positive association between the enlargement of the enterprising family and the attractiveness of $\mathrm{CV}$ described in the previous stage remain true, the motivation will decrease without reaching the level we proposed for the first stage of enterprising family development. We, thus, propose the following:

Proposition 1d: As the enterprising family moves from the working together stage through the passing the baton stage, motivation for corporate venturing decreases.

The family business developmental model describes the development of the family firm along three dimensions - family, ownership, and business - that can vary independently (Gersick et al., 1997). Timing and sequencing of family events (i.e., FDD) represent the foundation of our conceptualization, and Propositions 1a to $1 \mathrm{~d}$ assume that the family firm is positioned in the early stages of the other two developmental dimensions. However, our model also accounts for the contingent effect of a progression along ownership and business developmental dimensions. Particularly, the evolution of the family business ownership structure (i.e., the ODD) is described next, and we later elaborate on the development of the business (i.e., the BDD).

\section{Ownership development and motivation for corporate venturing}

When a family firm proceeds along its ownership developmental dimension, shares become increasingly dispersed among a growing number of family owners, and the overlap between business and family norms and roles decreases (Miller, Le Breton-Miller, and Lester, 2011). The ownership structure becomes more complex: some family members withdraw their roles and nonfamily members or newly affiliated members obtain shares of the business (Gersick et al., 1997). Late ODD is characterized by an increasing level of potential rivalries among 
family members from different family branches involved in the business (Lim, Lubatkin, and Wiseman, 2010). Ownership development also implies that family members might experience less emotional attachment and decreased identification with the family business, as well as weaker ties with other family members (Le Breton-Miller and Miller, 2013). Outsider involvement reflects family willingness to relinquish control and is associated with more formal control systems (Gómez-Mejía et al., 2011).

Considering FDD evolution when the firm is in late ODD, we expect distinctive patterns of motivation for $\mathrm{CV}$ to emerge. Particularly, the negative effect of the parents' provider norm on motivation for $\mathrm{CV}$ at the young business family stage is mitigated because family wealth is more diversified and there is less overlap between family and business resources. Each nuclear family is also less demanding of the business as a means to satisfy its own needs. All this implies that parents are both less risk averse and less locked into the family. Thus, motivation for CV is higher compared to early ODD.

At the entering the business stage, we recall, the positive effect of parents as mentors and the negative effect of children as reluctant learners result in moderate motivation for $\mathrm{CV}$. Further investigating this stage in late ODD, the offspring find themselves in a context characterized by increased complexity-namely, ownership dispersion and definition of subidentities by family branches (Webb, Ketchen, and Ireland, 2010). The reluctance of offspring to embrace the family career and their eagerness toward an autonomous occupation outside the business are, thus, likely to be weaker. The enterprising family motivation for CV is higher compared to early ODD.

An alignment between mentor and learner is finally achieved at the working together stage. The family shows a collective commitment toward the business and the strategic succession process. This process involves the integration of in-laws within the enterprising family to ensure transgenerational entrepreneurship (Jaskiewicz et al., 2015). In late ODD, 
shares are dispersed among different family branches and the number of in-laws potentially involved in the business increases. In-law involvement in the family business through $\mathrm{CV}$ initiatives rather than through their integration in the core business is particularly attractive and appropriate for several reasons. First, the core business offers fewer available positions. Second, in-laws are employed through formalized procedures instead of nepotistic practices, and it is unlikely that ad hoc positions will be created for them within the parent company. Third, creating different businesses within the same family firm could help reduce conflicts among family members (potential successors or founder and successor) (Poza, 1988). Thus, at the working together stage, motivation for $\mathrm{CV}$ is even higher than in late ODD.

Finally, tensions and divergence in goals between parents and children, which are observed in the passing the baton stage, are added to and magnified by rivalries among the different family branches that are typical of late ODD (Kotlar and De Massis, 2013; Lim et al., 2010). Moreover, the presence of non-active family members within the ownership structure of a family firm - a common situation in late ODD — represents a threat for family cohesion. This risk is even higher in the case of a CV initiative (Marchisio et al., 2010). Cognizant of that, the enterprising family is likely to display a lower motivation for $\mathrm{CV}$ compared to early ODD:

Proposition 2: Ownership development interacts with family development to determine an enterprising family's motivation for corporate venturing. Specifically when: (1) an enterprising family evolves along the first three stages of the FDD, later positioning on the ODD is associated with higher motivation for corporate venturing compared to earlier positioning on the $O D D$; and (2) an enterprising family evolves along the fourth stage of the $F D D$, later positioning on the ODD is associated with lower motivation for corporate venturing compared to earlier positioning on the ODD.

\section{Business development and motivation for corporate venturing}

A progression along the BDD makes a larger stock of resources, such as financial slack (Greidanus, 2011; Kellermanns et al., 2008), human capital (Miller et al., 2015), and social capital (Zahra, 2010) available to the organization, and the family might be willing to invest 
it. Moreover, family firm principals become aware that it is necessary to professionalize the firm in order to manage its increasing size and the related complexities (Dekker et al., 2013). Similar to what happens along the ODD, business development might also lead to a decreased emotional attachment and lower identification with the family business (Le Breton-Miller and Miller, 2013). Finally, late BDD is also characterized by concerns about a potential decline in revenues and/or profits from the core business (Salvato, Chirico, and Sharma, 2010).

Considering family development in late BDD, we suggest distinctive patterns of motivation for $\mathrm{CV}$. At the young business family stage, the provider norm and the task of nurturing can be supported by income availability that is higher in later BDD stages (Chaulk et al., 2003). Hence, risk aversion decreases and enterprising family motivation for CV increases compared to early BDD (Greidanus, 2011).

As the firm grows and becomes professionalized in late BDD, working within the family business becomes much more attractive for offspring who are concerned about strengthening their skills and building their own careers. Accordingly, the likelihood that they will pursue an autonomous career path outside the family firm is lower. Hence, offspring will engage more quickly with the business, manifest higher learning proclivity, and act as stewards of the organization. Within this configuration, the parent-child alignment is strong: entrepreneurial education and bridging - typical strategic activities of the entering the business and working together stages, respectively - are enhanced. A stewardship mind-set leads the family to place higher priority on the establishment of new entrepreneurial initiatives in order to rejuvenate the business (prevalence of business-first norms). Hence, in late BDD, we expect an increased motivation for $\mathrm{CV}$ at both the second and third stages of family development compared to early BDD. 
At the passing the baton stage, professionalization helps in the process of power transfer and mitigates conflicts between generations. Moreover, taking care of aging parents is facilitated in late BDD by the larger availability of resources. Tension between the two family norms of taking care of parents and supporting the growth of the family decreases; thus, the decline in motivation for $\mathrm{CV}$ initiatives is less prominent in late BDD.

Overall, the previously mentioned arguments support the idea of a positive interaction effect of business development on the relationship between family development and CV initiatives:

Proposition 3: Business development interacts with family development to determine an enterprising family's motivation for corporate venturing. Specifically, when an enterprising family evolves along the four stages of the $F D D$, later positioning on the BDD is associated with higher motivation for corporate venturing compared to earlier positioning on the $B D D$.

\section{The effect of motivation for corporate venturing on family development}

The stimuli for family developmental growth, and the pressure to move from one stage to the next in the family career, arise from two highly interdependent sources. First there are family developmental tasks, which are functions the enterprising family has to accomplish in order to survive (e.g., physical maintenance, reproduction of new group members, and socialization of new group members) and which require family members to develop, alter, or reallocate important roles within the family (Cunningham, 1978; Mattessich and Hill, 1987; Rodgers, 1964). Second there are recurrent life stresses - namely, the residue of tension generated by unmanaged events or stressors (e.g., transition to parenthood, child leaving, and launching) that can force families into major reorganization (Laszloffy, 2002; Mattessich and Hill, 1987; McCubbin et al., 1980). 
Building on the theory of family development, we predict that the emergence of motivation for $\mathrm{CV}$ initiatives may, in itself, have an effect on the development of the enterprising family. The mechanism lies in the supposition that the motivation for CV can generate some types of stress and a shift in family roles, relationships, and tasks. Hereafter, we develop some illustrative arguments.

The well-being of children is a long-lasting concern throughout the family development that becomes particularly salient in the transition from the young family business to the entering the business stage. While the topic has received overriding interest from family scholars, it is a consequence of entrepreneurial activities in family business that is overlooked by family business research (James, Jennings, and Breitkreuz, 2012). Based on our conceptual model and existing studies (Aldrich, Renzulli, and Langton, 1998), we propose that, overall, parents' motivations for venturing can provide new generation members with unique learning opportunities that facilitate the family task of children's progress toward independent self-support-individuation or differentiation (Kaye, 1996). In fact, when the enterprising family strives for $\mathrm{CV}$, children are exposed to and benefit from opportunities to develop work-related skills, values, experience, and connections (James et al., 2012).

In addition, the motivation of incumbent family members to establish a new venture may cause decisions about children's careers and particularly influence children's evaluations regarding joining the family business (a typical stressor of the transition into the entering the business stage). It may be that offspring are likely to evaluate as attractive a family business with prospects of new business venturing (Greidanus, 2011). At this stage, these prospects might bring excitement, innovation, autonomy, and room for development of their own family entrepreneurial legacy (Jaskiewicz et al., 2015). Conversely, a conservative and riskaverse enterprising family, with no motivation to venture, is possibly detrimental in recruiting 
offspring into the firm. The same is true also in the progression toward the final stage of family development, with severe consequences for succession (Greidanus, 2011).

Some scholars have depicted the business as a curb or an illness for the enterprising family and its members (Kaye, 1996). The role of parents should be to develop children's individuation and let them enjoy rewarding ties with the extended family. However, cases are reported of family businesses whose owners utilize the firm to delay the regular development of their family and their children. When parents, for example, are reluctant to support $\mathrm{CV}$, they defer the development of their children and themselves. This prevents the fulfillment of family tasks and generates stress. Thus, family development is at stake, and its progress is severely inhibited. Summarizing, reduced motivation for $\mathrm{CV}$ is likely to prevent the enterprising family from developing.

Overall, we suggest that:

Proposition 4: The enterprising family's motivation for corporate venturing spurs its progression along the family developmental dimension.

\section{DISCUSSION}

Drawing on family development theory (Rodgers, 1964; Rodgers and White, 1993), we elaborate a conceptual model that illustrates when and why enterprising families are motivated toward CV. Our work suggests that institutional and normative aspects of family development influence the motivation of enterprising families for CV initiatives. Motivation for $\mathrm{CV}$ increases across the first three stages of family development before decreasing in the last stage, when a shift in responsibilities and roles in the parent-offspring relationship occurs. Additionally, this study leverages the family business developmental model (Gersick et al., 1997) to explain how family development interacts with firm-related developmental dimensions (Hoy, 2006; Sharma, Salvato, and Reay, 2014). According to our predictions, in late ODD and BDD, the effects of family development are strengthened. Finally, our model accounts for a feedback influence: the enterprising family may progress along its family 
developmental stages as a result of, and as a response to, increasing levels of motivation for CV.

Overall, our article supports the idea that enterprising families are actors likely to engage in continuous renewal and repeated acts of entrepreneurship. In particular, we speculate that motivation for $\mathrm{CV}$ depends on family dynamics associated with the natural evolution of norms through subsequent family stages (Rodgers and White, 1993). In this view, our model reifies the metaphor that represents families as the 'oxygen that fuels the fire of entrepreneurship' (Rogoff and Heck, 2003: 561), but also extends it by portraying the family as the water that can extinguish it. Moreover, the mutual influence of family development and entrepreneurial motivation indicates that the enterprising family can be the place in which a long-lasting pattern of enduring entrepreneurship occurs (Lumpkin and Brigham, 2011).

Our conceptualization offers several contributions to both the entrepreneurship and family business literatures. First, while 'very little attention has been paid to how family dynamics affect fundamental entrepreneurial processes' (Aldrich and Cliff, 2003: 573-574; Miller et al., 2016), our work offers a family-related approach to entrepreneurship and CV (Marchisio et al., 2010; Rogoff and Heck, 2003). Particularly, the use of family development theory substantiates that family-related approaches have great potential to advance the study of entrepreneurship, because they capture the pervasive effect of family embeddedness and the value of transgenerational processes behind any entrepreneurial initiative (Jennings et al., 2013). The focus on the family also allows us to extend to internal factors the notion of corporate entrepreneurship triggers that is predominantly used by scholars in this field of research (Kuratko, 2010). In fact, while existing literature tends to focus on antecedents of corporate entrepreneurship that are exogenous to the business (e.g., intense competition, rapid technological change, and short product life cycles), we elaborate on the role of factors that are endogenous to the organization in influencing the firm's motivation for CV. 
Second, we contribute to research on entrepreneurship in a family business by elaborating on the motivation for corporate venturing. Existing literature acknowledges the importance of entrepreneurial motivation (Shane et al., 2003)-for instance, individuals acting entrepreneurially within an organization (Brundin et al., 2008). Motivation is also a key success factor during a succession process (Jaskiewicz et al., 2015). However, little is known about the reasons behind entrepreneurial initiatives and particularly the motivations of the enterprising family (Michael-Tsabari et al., 2014; De Massis et al., 2014b). Our research addresses this gap by speculating on the relationship between family development, the development of the whole family business system (including ownership and business), and the enterprising family motivation for CV.

Third, we suggest a dynamic view of the motivation for $\mathrm{CV}$ within enterprising families and address two timely issues. On the one hand, our model goes beyond the general and rigid classification of family firms as either very or minimally entrepreneurial and studies the evolution of enterprising families' motivation for CV over time. On the other hand, it offers a nuanced characterization of family firms through behavioral and time-related mechanisms, which are decisive for the advancement of family business studies (Gagné, Sharma, and De Massis, 2014; De Massis et al., 2014b).

Fourth, building on the central tenets of family development theory, we offer an extension of Gersick et al.'s (1997) framework. While having some merits in conceptualizing family firms as inherently developmental, often the framework has been criticized for being practice-based and anecdotal (Berent-Braun and Uhlaner, 2012; Carney and Jaskiewicz, 2015; Rutherford et al., 2006). By blending family development theory and the family business developmental model, we provide a more nuanced, rigorous, and normative description of the FDD stages and the reasons that enterprising families behave entrepreneurially across these stages. Furthermore, we highlight how the combination of 
different and even competing pressures, triggered by distinct developmental dimensions, results in a weakening or strengthening of CV motivations. In so doing, we respond to Hoy's (2006: 831) call to understand how the 'complicating factors of life cycle' affect CV in family firms.

Finally, the feedback influence suggested by our model represents an attempt to respond to scholars calling for further exploration of the effects of entrepreneurship on the family system (Sciascia and Bettinelli, 2015; see also Aldrich and Cliff, 2003). We postulate that as motivation for $\mathrm{CV}$ increases, this spurs the development of the enterprising family by making the children independent, self-supporting, and keen on joining the family business. This, in turn, is likely to influence subsequent motivation for $\mathrm{CV}$. Thus, we propose a virtuous cycle whereby corporate venturing becomes increasingly established within the enterprising family. Furthermore, in our model, the decline of motivation for $\mathrm{CV}$ in the passing the baton stage does not drop to the initial level of the young family business stage. We suggest that there is a sort of progressive and enduring path toward entrepreneurship that is supported by-and which, in turn, reinforces - enterprising family well-being and development. This longlasting mechanism depicts the enterprising family as a springboard for repeated acts of entrepreneurship across generations (Jaskiewicz et al., 2015; Sieger et al., 2011).

\section{Implications for theory and research}

To the extent that our propositions remain compelling in other settings, a theory of family motivation for $\mathrm{CV}$ is possible and could inform a more general theory of family entrepreneurship. In line with a midrange theoretical approach, the conceptual model presented here can be further extended (for example, by relaxing the assumptions inherent to our propositions), thus moving toward the elaboration of a theory of larger scope (Merton, 1949; Pinder and Moore, 1978). Given the boundaries of our theoretical elaboration, further efforts may consider: (1) additional sources of heterogeneity within families (e.g., differences 
in identification processes of individuals) and among families (e.g., extended families made of numerous nuclear families) as they develop over time; (2) different cultural and institutional contexts other than the North American one; and (3) complexity of enterprising family developmental patterns. Hereafter, we propose a few suggestions for this extension.

Challenging the implicit assumption that members of an enterprising family are 'predisposed to behave in a homogeneous manner' (James et al., 2012: 94), further research may draw on social identity theory (Ashforth and Mael, 1989) to discuss how individuals identify themselves within groups different from the family (e.g., religious, political). This might help in investigating whether, how, and when their norms and roles detach from our predictions and. so. from motivation for CV. Also, social identity theory may shed light on the effects of family development on motivation for $\mathrm{CV}$ when considering the presence of multiple family branches. Since individual family members may identify with their own branch more than with the extended enterprising family, and do so differently along the stages of family development, it might be interesting to study the role of governance mechanisms (Jaffe and Lane, 2004); in particular, further theorizing could integrate communication and collaboration processes and how they cope with the normative heterogeneity across branches that is likely to occur at different stages of their family development.

Second, in line with family development literature, we relied upon a universal model of family (White, 1984). Relaxing this assumption-for instance, by considering a different cultural and geographical context-may extend the scope of our theory. We recognize also that our use of Gersick et al.'s (1997) framework builds on the same limiting assumption: it is based on the average American family, settled in the mid- and western U.S., representing wealthy, medium-sized, second- and third-generation family firms (Carney and Jaskiewicz, 2015). Scholars suggest using greater caution regarding the definition of family and to 
consider the formation and dissolution of kinship ties across the household boundaries when defining the entrepreneurial family (Aldrich and Cliff, 2003). A Japanese stem family, for example, with two or three generations sharing the same household, or a Chinese patrilineal family, with all male descendants living together until the parents pass away, represent different models of family, which can significantly influence how roles and norms change over time (Morioka, 1967). Also, considering other contexts, with their formal and informal institutions, might enlarge the scope of our conceptual model. For instance, the roles of parents who have to take care of one or more children in the young business family stage or of children who have to take care of aging parents during the passing the baton stage might differ in countries with public rather than private health care systems (e.g., Europe and the U.S.). Other examples of sociocultural institutions that could affect our model are: the onechild rule of Chinese families; sociocultural values, such as acceptance of failure or masculinity at the country level (Hofstede, 1983); and the zeitgeist effect that suggests that two identical families living in different time cohorts might develop and behave differently (Wyrwich, 2013). By comparing different contexts or by developing longitudinal analyses, the effect of changing norms and roles on motivation for $\mathrm{CV}$ could be explained with a broader theoretical scope.

Third, by building on Gersick et al.'s (1997) family business developmental model, our predictions are biased toward a progressive evolution of all the three dimensions (family, ownership, and business). While progress along the family developmental dimension is irreversible, the family business may follow different-and non-necessarily progressivedevelopmental patterns along the ODD and the BDD. For example, ownership dispersion may range from primogeniture, in which the first-born inherits all the equity and the ownership structure remains the same as in the previous generation, to coparcenary, in which offspring receive relatively equal shares (Schulze, Lubatkin, and Dino, 2003). But, as the 
enterprising family develops, its business may also fail, or be sold, before reaching the maturity stage (e.g., Salvato et al., 2010). As these events may affect the norms that characterize the development of the enterprising family and be the source of new stresses that can influence the motivation for $\mathrm{CV}$, future extensions of our model may consider nonprogressive ownership and business developmental patterns and their effect on motivation for $\mathrm{CV}$.

Additional future research directions may emerge from this study and enrich the field of entrepreneurship in family firms. First, further elaboration on the coevolution of the different developmental dimensions seems worthwhile. For example, a three-way interaction of the family, ownership, and business developmental dimensions may offer additional insights into the motivation for $\mathrm{CV}$, shedding further light on the complicating factor of life cycles (Hoy, 2006). Moreover, product, technology, or industry life cycles may be external triggers of entrepreneurship that can interact with our developmental dimensions that are endogenous to the family business system. Second, future research may consider the family development effect on further entrepreneurship endeavors - such as the preference for internal, cooperative, or external venturing (Sharma and Chrisman, 1999; Williams and Lee, 2009; Calabrò et al., 2016) or manifestations such as entrepreneurial orientation (Cruz and Nordqvist, 2012) or strategic renewal (Sharma and Chrisman, 1999) — and do so in different organizational contexts (e.g., public versus private firms). Similarly, an enterprising familyrelated perspective could also be regarded as valuable to investigate family business' preferences for exploration or exploitation, namely two activities deemed as crucial for the survival, growth, and renewal of businesses in general and family firms in particular (Goel and Jones, 2016). In short, we recognize that corporate venturing — new business creation-is not the only manifestation that corporate entrepreneurship may take within a family firm, and future research to examine other typologies of entrepreneurial initiatives in family businesses 
is encouraged. In order to enhance the predictive power of our work, we chose to focus on a specific entrepreneurial manifestation at the firm level-that is, CV. The latter indeed represents the entrepreneurial activity most likely to extend the operational domain of the family firm in such a way as to provide greater opportunities to growing enterprising families. Third, dimensions other than motivation are also worth considering for the study of firm behavior. For example, by looking at resources and capabilities (Miller et al., 2015), research aiming to predict actual family businesses engagement in $\mathrm{CV}$ will have to extend family development theory's normative and motivational arguments with resource- and capability-based views (Dyer et al., 2014; Sieger et al., 2011).

\section{Implications for practice}

The propositions derived from our conceptual model offer insightful implications for practice, thus filling the gap of practical knowledge on enterprising families as compared to family businesses noted by De Massis and Kotlar (2015). Enterprising families, resource providers (such as banks or private equity funds), advisors, and educators, in addition to policy makers, can obtain information relevant for their work. Enterprising families may be aware of the fact that the roles of the different members determine the alignment of motivation for $\mathrm{CV}$ and that the transitions toward the stage of entering the business and working together are especially delicate. Offspring motivation for CV at those stages should be accompanied by, for instance, investments in training and education. Moreover, nascent entrepreneurs and corporations may benefit from our speculations when they approach a family firm as corporate incubator or as partner, respectively, for their entrepreneurial initiatives (e.g., Au et al., 2013). 
Resource providers might consider the findings of this study as a way to distinguish family-related from business-related dynamics when they evaluate the funding of family businesses. Consulting firms and educators may derive from our conceptual model a perspective to better approach, mentor, and advise enterprising family members. In fact, when motivation for $\mathrm{CV}$ is high, so is the learning proclivity; this, in turn, is likely to increase the effectiveness of educational and training programs, both generally and specifically in relation to entrepreneurship. Furthermore, recent research has indicated that the engagement of families in entrepreneurship worldwide is paramount (James et al., 2012) and that public policies should be aware of the pervasive family effect in entrepreneurship (Aldrich and Cliff, 2003). Hence, our contribution could be valuable to policy makers because by observing family-related demographic trends within a region, they could gather a deeper understanding about the overall level of new firm creation.

\section{CONCLUSION}

In sum, we suggest that family firms especially foster $\mathrm{CV}$ in the later stages of family, ownership, and business developmental dimensions. Specifically, family firms who survive at least two ownership succession processes and/or grow up to the maturity phase and whose family members face the working together stage in their entrepreneurial family, experience and nurture enduring entrepreneurship by engaging in $\mathrm{CV}$. In a sense, they enter a virtuous cycle that rewards, with a heightened interest in entrepreneurial initiatives, their efforts to overcome the challenges encountered during the previous transitions from stage to stage.

By viewing the establishment of new ventures as family-related endeavors, we provide a unique contribution to understand why firms engage in repeated acts of entrepreneurship. Building on our propositions and integrating major family and management business theories, we encourage future research to explore this perspective further and, thus, contribute to both 
the entrepreneurship and the family business fields from a theoretical and practical point of view.

\section{ACKNOWLEDGEMENTS}

Support for this research was provided by the Italian Ministry of Education, University and Research (PRIN 2010-11 Research Grant 'Scientific research and competitiveness: variety of organizations, support systems, and performance levels'). We would like to thank Anita Van Gils, Mattias Nordqvist, Frank Hoy, Justin Craig, the special issue editors, and three anonymous reviewers for their helpful comments on earlier versions of this article. We appreciate the insightful comments offered by the participants at the Academy of Management 2015 Annual Meeting, the 2014 AiIG Annual Scientific Meeting, and the 2014 Workshop on Family Firm Management Research (EIASM).

\section{REFERENCES}

Aldous J. 1978. Family Careers: Developmental Change in Families. John Wiley \& Sons: New York.

Aldrich HE, Cliff JE. 2003. The pervasive effects of family on entrepreneurship: toward a family embeddedness perspective. Journal of Business Venturing 18(5): 573-596.

Aldrich HE, Renzulli LA, Langton N. 1998. Passing on privilege: resources provided by selfemployed parents to their self-employed children. In Research in Social Stratification and Mobility, Leicht K (ed). JAI Press: Greenwich, CT; 291-318.

Ashforth BE, Mael F. 1989. Social identity theory and the organization. Academy of Management Review 14(1): 20-39.

Au K, Chiang FF, Birtch TA, Ding Z. 2013. Incubating the next generation to venture: the case of a family business in Hong Kong. Asia Pacific Journal of Management 30(3): $749-767$. 
Bates FL. 1956. Position, role, and status: a reformulation of concepts. Social Forces 34: $313-321$.

Berent-Braun MM, Uhlaner LM. 2012. Family governance practices and teambuilding: paradox of the enterprising family. Small Business Economics 38(1): 103-119.

Bertrand M, Schoar A. 2006. The role of family in family firms. Journal of Economic Perspectives 20(2): 73-96.

Block JH. 2012. R\&D investments in family and founder firms: an agency perspective. Journal of Business Venturing 27(2): 248-265.

Bloom N, Van Reenen J. 2007. Measuring and explaining management practices across firms and countries. Quarterly Journal of Economics 122(4): 1351-1408.

Brundin E, Patzelt H, Shepherd DA. 2008. Managers' emotional displays and employees' willingness to act entrepreneurially. Journal of Business Venturing 23(2): 221-243.

Calabrò A, Minola T, Campopiano G, Pukall T. 2016. Turning innovativeness into domestic and international corporate venturing: the moderating effect of high family ownership and influence. European Journal of International Management 10(5): 505-533.

Carney M, Jaskiewicz P. 2015. Six books that have shaped the landscape of family business scholarship. Academy of Management Learning \& Education 14(3): 423-429.

Chaulk B, Johnson PJ, Bulcroft R. 2003. Effects of marriage and children on financial risk tolerance: a synthesis of family development and prospect theory. Journal of Family and Economic Issues 24(3): 257-279.

Chirico F, Sirmon DG, Sciascia S, Mazzola P. 2011. Resource orchestration in family firms: investigating how entrepreneurial orientation, generational involvement, and participative strategy affect performance. Strategic Entrepreneurship Journal 5(4): 307326. 
Chua JH, Chrisman JJ, Sharma P. 1999. Defining the family business by behavior. Entrepreneurship Theory and Practice 23(4): 19-39.

Churchill NC, Hatten KJ. 1997. Non-market-based transfers of wealth and power: a research framework for family business. Family Business Review 10(1): 53-67.

Corbetta G, Salvato C. 2004. Self-serving or self-actualizing? Models of man and agency costs in different types of family firms: a commentary on 'Comparing the agency costs of family and non-family firms: conceptual issues and exploratory evidence.' Entrepreneurship Theory and Practice 28(4): 355-362.

Covin JO, Miles MP. 1999. Corporate entrepreneurship and the pursuit of competitive advantage. Entrepreneurship Theory and Practice 23(3): 47-63.

Cruz C, Nordqvist M. 2012. Entrepreneurial orientation in family firms: a generational perspective. Small Business Economics 38(1): 33-49.

Cunningham J. 1978. Conceptualizing the organizational and family relationship. International Journal of Sociology of the Family 8(2): 195-206.

Davis JA, Tagiuri R. 1989. The influence of life stage on father-son work relationships in family companies. Family Business Review 2(1): 47-74.

Davis JH, Schoorman FD, Donaldson L. 1997. Toward a stewardship theory of management. Academy of Management Review 22(1): 20-47.

Dekker JC, Lybaert N, Steijvers T, Depaire B, Mercken R. 2013. Family firm types based on the professionalization construct: exploratory research. Family Business Review 26(1): $81-99$.

De Massis A, Chirico F, Kotlar J, Naldi L. 2014a. The temporal evolution of proactiveness in family firms: the horizontal S-curve hypothesis. Family Business Review 27(1): 35-50. 
De Massis A, Kotlar J. 2015. Learning resources for family business education: a review and directions for future developments. Academy of Management Learning \& Education 14(3): 415-422.

De Massis A, Kotlar J, Chua JH, Chrisman JJ. 2014b. Ability and willingness as sufficiency conditions for family-oriented particularistic behavior: implications for theory and empirical studies. Journal of Small Business Management 52(2): 344-364.

Duvall EM. 1957. Family Development. Lippincott: Philadelphia, PA.

Dyer WG, Nenque E, Hill EJ. 2014. Toward a theory of family capital and entrepreneurship: antecedents and outcomes. Journal of Small Business Management 52(2): 266-285.

Eddleston KA, Kellermanns FW. 2007. Destructive and productive family relationships: a stewardship theory perspective. Journal of Business Venturing 22(4): 545-565.

Fletcher D. 2010. 'Life-making or risk taking?' Co-preneurship and family business start-ups. International Small Business Journal 28(5): 452-469.

Gagné M, Sharma P, De Massis A. 2014. The study of organizational behaviour in family business. European Journal of Work and Organizational Psychology 23(5): 643-656.

Gersick KE, Davis JA, Hampton MM, Lansberg I. 1997. Generation to Generation: Life Cycles of the Family Business. Harvard Business School Press: Boston, MA.

Goel S, Jones RJ III. 2016. Entrepreneurial exploration and exploitation in family business: a systematic review and future directions. Family Business Review 29(1): 94-120.

Gómez-Mejía LR, Cruz C, Berrone P, De Castro J. 2011. The bind that ties: socioemotional wealth preservation in family firms. Academy of Management Annals 5(1): 653-707.

Gómez-Mejía LR, Haynes KT, Núñez-Nickel M, Jacobson KJ, Moyano-Fuentes J. 2007. Socioemotional wealth and business risks in family-controlled firms: evidence from Spanish olive oil mills. Administrative Science Quarterly 52(1): 106-137. 
Greidanus NS. 2011. Corporate venturing in family firms: a strategic management approach. International Journal of Entrepreneurial Venturing 3(2): 125-148.

Greidanus NS, Märk S. 2012. An exploration of internal corporate venturing goals in family firms. Journal of Small Business \& Entrepreneurship 25(2): 169-183.

Gross N, Mason WS, McEachern AW. 1958. Explorations in Role Analysis: Studies of the School Superintendency Role. Wiley: New York.

Habbershon TG. 2006. Commentary: a framework for managing the familiness and agency advantages in family firms. Entrepreneurship Theory and Practice 30(6): 879-886.

Habbershon TG, Pistrui J. 2002. Enterprising families domain: family-influenced ownership groups in pursuit of transgenerational wealth. Family Business Review 15(3): 223-237.

Hofstede G. 1983. The cultural relativity of organizational practices and theories. Journal of International Business Studies 14(2): 75-89.

Hoy F. 2006. The complicating factor of life cycles in corporate venturing. Entrepreneurship Theory and Practice 30(6): 831-836.

Hoy F. 2012. Book review: Keeping the Family Business Healthy: How to Plan for Continuing Growth, Profitability, and Family Leadership. Family Business Review 25(1): 117-120.

Jaffe DT, Lane SH. 2004. Sustaining a family dynasty: key issues facing complex multigenerational business- and investment-owning families. Family Business Review 17(1): 81-98.

James AE, Jennings JE, Breitkreuz RS. 2012. Worlds apart? Rebridging the distance between family science and family business research. Family Business Review 25(1): 87-108.

Jaskiewicz P, Combs JG, Rau SB. 2015. Entrepreneurial legacy: toward a theory of how some family firms nurture transgenerational entrepreneurship. Journal of Business Venturing 30(1): 29-49. 
Jennings JE, Breitkreuz RS, James AE. 2013. Theories from family science: a review and roadmap for family business research. In The SAGE Handbook of Family Business, Melin L, Nordqvist M, Sharma P (eds). SAGE Publications: London, U.K.; 25-46.

Kaye K. 1996. When the family business is a sickness. Family Business Review 9(4): 347368.

Kellermanns FW, Eddleston KA. 2006. Corporate entrepreneurship in family firms: a family perspective. Entrepreneurship Theory and Practice 30(6): 809-830.

Kellermanns FW, Eddleston KA, Barnett T, Pearson A. 2008. An exploratory study of family member characteristics and involvement: effects on entrepreneurial behavior in the family firm. Family Business Review 21(1): 1-14.

Kotlar J, De Massis A. 2013. Goal setting in family firms: goal diversity, social interactions, and collective commitment to family-centered goals. Entrepreneurship Theory and Practice 37(6): 1263-1288.

Kuratko DF. 2010. Corporate entrepreneurship: an introduction and research review. In Handbook of Entrepreneurship Research, Acs ZJ, Audretsch DB (eds). Springer: New York; 129-163.

Laszloffy TA. 2002. Rethinking family development theory: teaching with the systemic family development (SFD) model. Family Relations 51(3): 206-214.

Le Breton-Miller I, Miller D. 2013. Socioemotional wealth across the family firm life cycle: a commentary on 'Family business survival and the role of boards.' Entrepreneurship Theory and Practice 37(6): 1391-1397.

Lim EN, Lubatkin MH, Wiseman RM. 2010. A family firm variant of the behavioral agency theory. Strategic Entrepreneurship Journal 4(3): 197-211.

Lumpkin GT, Brigham KH. 2011. Long-term orientation and intertemporal choice in family firms. Entrepreneurship Theory and Practice 35(6): 1149-1169. 
Lumpkin GT, Steier L, Wright M. 2011. Strategic entrepreneurship in family business. Strategic Entrepreneurship Journal 5(4): 285-306.

Marchisio G, Mazzola P, Sciascia S, Miles M, Astrachan J. 2010. Corporate venturing in family business: the effects on the family and its members. Entrepreneurship and Regional Development 22(3/4): 349-377.

Mattessich P, Hill R. 1976. Family enterprise and societal development: a theoretical assessment. Journal of Comparative Family Studies 7(2): 147-158.

Mattessich P, Hill R. 1987. Life cycle and family development. In Handbook of Marriage and the Family, Sussman MB, Steinmetz SK (eds). Springer: New York; 437-469.

McCubbin HI, Joy CB, Cauble AE, Comeau JK, Patterson JM, Needle RH. 1980. Family stress and coping: a decade review. Journal of Marriage and the Family 42(4): 855-871.

McCubbin HI, Patterson JM. 1983. The family stress process: the double ABCX model of adjustment and adaptation. Marriage \& Family Review 6(1/2): 7-37.

McKelvie A, McKenney A, Lumpkin G, Short JC. 2013. Corporate entrepreneurship in family businesses: past contributions and future opportunities. In The SAGE Handbook of Family Business, Melin L, Nordqvist M, Sharma P (eds). SAGE Publications: London, U.K.; 340-362.

Merton RK. 1949. On sociological theories of the middle range. In Social Theory and Social Structure, Merton RK (ed). Simon \& Schuster: NewYork; 39-53.

Michael-Tsabari N, Labaki R, Zachary RK. 2014. Toward the cluster model: the family firm's entrepreneurial behavior over generations. Family Business Review 27(2): 161185.

Miles MP, Covin JG. 2002. Exploring the practice of corporate venturing: some common forms and their organizational implications. Entrepreneurship Theory and Practice 26(3): 21-40. 
Miller D, Le Breton-Miller I. 2005. Managing for the Long Run: Lessons in Competitive Advantage from Great Family Businesses. Harvard Business School Press: Boston, MA.

Miller D, Le Breton-Miller I, Lester RH. 2011. Family and lone founder ownership and strategic behaviour: social context, identity, and institutional logics. Journal of Management Studies 48(1): 1-25.

Miller D, Steier L, Le Breton-Miller I. 2016. What can scholars of entrepreneurship learn from sound family businesses? Entrepreneurship Theory and Practice 40(3): 445-455.

Miller D, Wright M, Le Breton-Miller I, Scholes L. 2015. Resources and innovation in family businesses: the Janus-face of socioemotional preferences. California Management Review 58(1): 20-40.

Minola T, Criaco G, Obschonka M. 2016. Age, culture, and self-employment motivation. Small Business Economics 46(2): 187-213.

Morioka K. 1967. Life cycle patterns in Japan, China, and the United States. Journal of Marriage and the Family 29(3): 595-606.

Morris M, Kuratko D, Covin J. 2010. Corporate Entrepreneurship \& Innovation. SouthWestern: Mason, $\mathrm{OH}$.

Nordqvist M, Melin L. 2010. Entrepreneurial families and family firms. Entrepreneurship and Regional Development 22(3/4): 211-239.

Paul JJ, Winter M, Miller NJ, Fitzgerald MA. 2003. Cross-institutional norms for timing and sequencing and the use of adjustment strategies in families affiliated with family-owned businesses. Marriage \& Family Review 35(1/2): 167-191.

Pinder CC, Moore LF. 1978. Middle Range Theory and the Study of Organizations. Martinus Nijhoff Publishing: Leiden, The Netherlands.

Poza EJ. 1988. Managerial practices that support interpreneurship and continued growth. Family Business Review 1(4): 339-359. 
Rodgers RH. 1964. Toward a theory of family development. Journal of Marriage and the Family 26(3): 262-270.

Rodgers RH, White JM. 1993. Family development theory. In Sourcebook of Family Theories and Methods, Boss P, Doherty WJ, LaRossa R, Schumm WR, Steinmetz SK (eds). Springer: New York; 225-257.

Rogoff EG, Heck RKZ. 2003. Evolving research in entrepreneurship and family business: recognizing family as the oxygen that feeds the fire of entrepreneurship. Journal of Business Venturing 18(5): 559-566.

Rutherford MW, Muse LA, Oswald SL. 2006. A new perspective on the developmental model for family business. Family Business Review 19(4): 317-333.

Salvato C, Chirico F, Sharma P. 2010. A farewell to the business: championing exit and continuity in entrepreneurial family firms. Entrepreneurship and Regional Development 22(3/4): 321-348.

Schulze WS, Lubatkin MH, Dino RN. 2003. Exploring the agency consequences of ownership dispersion among the directors of private family firms. Academy of Management Journal 46(2): 179-194.

Sciascia S, Bettinelli C. 2013. Part III: corporate entrepreneurship in context: 1. corporate entrepreneurship in family businesses: past, present and future research.M@n@gement 16(4): 422-432.

Sciascia S, Bettinelli C. 2015. Corporate family entrepreneurship: the seven circumstances. In Family Entrepreneurship: Rethinking the Research Agenda, Randerson K, Bettinelli C, Dossena G, Fayolle A (eds). Routledge: New York; 47-70.

Shane S, Locke EA, Collins CJ. 2003. Entrepreneurial motivation. Human Resource Management Review 13(2): 257-279. 
Sharma P, Chrisman SJJ. 1999. Toward a reconciliation of the definitional issues in the field of corporate entrepreneurship. Entrepreneurship Theory and Practice 23(3): 11-26.

Sharma P, Salvato C, Reay T. 2014. Temporal dimensions of family enterprise research. Family Business Review 27(1): 10-19.

Sieger P, Minola T. The family's financial support as a 'poisoned gift:' a family embeddedness perspective on entrepreneurial intentions. Journal of Small Business Management. Forthcoming.

Sieger P, Zellweger T, Nason RS, Clinton E. 2011. Portfolio entrepreneurship in family firms: a resource-based perspective. Strategic Entrepreneurship Journal 5(4): 327-351.

Stafford K, Duncan KA, Dane S, Winter M. 1999. A research model of sustainable family businesses. Family Business Review 12(3): 197-208.

Tagiuri R, Davis J. 1996. Bivalent attributes of the family firm. Family Business Review 9(2): 199-208.

Ward JL. 1987. Keeping the Family Business Healthy: How to Plan for Continuing Growth, Profitability, and Family Leadership. Jossey-Bass: San Francisco, CA.

Webb JW, Ketchen DJ, Ireland RD. 2010. Strategic entrepreneurship within familycontrolled firms: opportunities and challenges. Journal of Family Business Strategy 1(2): $67-77$.

White JM. 1984. A cohort analysis of the family career. Journal of Comparative Family Studies 15(1): 29-41.

White JM. 1991. Dynamics of Family Development: A Theoretical Perspective. Guilford Press: New York.

Williams C, Lee SH. 2009. Exploring the internal and external venturing of large R\&D-intensive firms. $R \& D$ Management 39(3): 231-246. 
Wyrwich M. 2013. Can socioeconomic heritage produce a lost generation with regard to entrepreneurship? Journal of Business Venturing 28(5): 667-682.

Zahra SA. 2003. Ownership involvement and international expansion: an empirical test of the stewardship theory among family firms. Journal of Business Venturing 18(4): 495-512.

Zahra SA. 2010. Harvesting family firms' organizational social capital: a relational perspective. Journal of Management Studies 47(2): 345-366.

Zahra SA, Covin JG. 1995. Contextual influences on the corporate entrepreneurshipperformance relationship: a longitudinal analysis. Journal of Business Venturing 10(1): $43-58$.

Zellweger TM, Nason RS, Nordqvist M, Brush CG. 2013. Why do family firms strive for nonfinancial goals? An organizational identity perspective. Entrepreneurship Theory and Practice 37(2): 229-248. 
Table 1. Family development theory tenets through the stages of the family

\section{developmental dimension}

\begin{tabular}{|c|c|c|c|c|}
\hline \multirow{3}{*}{$\begin{array}{l}\text { Enterprising } \\
\text { family } \\
\text { developmental } \\
\text { stages (Gersick } \\
\text { et al., 1997) }\end{array}$} & \multicolumn{4}{|c|}{ Family developmental dimension } \\
\hline & $\begin{array}{|lll|}\begin{array}{l}\text { Young } \\
\text { stage }\end{array} & \text { business } & \text { family } \\
\end{array}$ & $\begin{array}{l}\begin{array}{l}\text { Entering the business } \\
\text { stage }\end{array} \\
\end{array}$ & Working together stage & Passing the baton stage \\
\hline & $\begin{array}{l}\text { Adult generation under } 40 ; \\
\text { children (if any) under } 18\end{array}$ & $\begin{array}{l}\text { Senior generation ages } 35 \text { to } \\
55 \text {; junior generation in } \\
\text { teens and twenties }\end{array}$ & $\begin{array}{l}\text { Senior generation ages } 50 \text { to } \\
65 \text {; junior generation ages } \\
20 \text { to } 45\end{array}$ & $\begin{array}{l}\text { Senior generation aged } 60 \\
\text { and above }\end{array}$ \\
\hline $\begin{array}{l}\text { Challenges } \\
\text { (Gersick et al., } \\
\text { 1997) }\end{array}$ & $\begin{array}{l}\text { Creating a workable } \\
\text { marriage enterprise; making } \\
\text { initial decisions about the } \\
\text { relationship between work } \\
\text { and family; working out } \\
\text { relationships with the } \\
\text { extended family; raising } \\
\text { children }\end{array}$ & $\begin{array}{l}\text { Managing the midlife } \\
\text { transition; separation and } \\
\text { individuation of the younger } \\
\text { generation; facilitating a } \\
\text { good process for initial } \\
\text { career decisions }\end{array}$ & $\begin{array}{l}\text { Fostering cross-generational } \\
\text { cooperation and } \\
\text { communication; } \\
\text { encouraging productive } \\
\text { conflict management; } \\
\text { managing the different } \\
\text { generations } \\
\text { together as family working }\end{array}$ & $\begin{array}{lc}\text { Senior } & \text { generation } \\
\text { disengaging } & \text { from the } \\
\text { business; } & \text { generational } \\
\text { transfer of family leadership }\end{array}$ \\
\hline $\begin{array}{l}\text { Family career: } \\
\text { positions and } \\
\text { roles (Rodgers, } \\
\text { 1964; } \\
\text { Mattessich and } \\
\text { Hill, 1987) }\end{array}$ & $\begin{array}{l}\text { Husband-father; } \\
\text { mother; child or child- } \\
\text { sibling }\end{array}$ & $\begin{array}{l}\text { Husband-father; } \\
\text { mother; child-sibling }\end{array}$ & $\begin{array}{l}\text { Husband-father-grandfather; } \\
\text { wife-mother-grandmother; } \\
\text { child-sibling-husband/wife- } \\
\text { father/mother; in-laws; } \\
\text { child-sibling-grandchild }\end{array}$ & $\begin{array}{l}\text { Husband-father-grandfather } \\
\text { (if applicable); wife-mother- } \\
\text { grandmother (if applicable); } \\
\text { child-sibling-husband/wife- } \\
\text { father/mother; in-laws; } \\
\text { child-sibling-grandchild }\end{array}$ \\
\hline $\begin{array}{l}\text { Stressors } \\
\text { (McCubbin et } \\
\text { al., 1980; } \\
\text { McCubbin and } \\
\text { Patterson, } \\
\text { 1983) }\end{array}$ & $\begin{array}{l}\text { Marriage; birth of first } \\
\text { child; birth of subsequent } \\
\text { children }\end{array}$ & $\begin{array}{l}\text { Children leaving home } \\
\text { (children launching); } \\
\text { children looking for a job } \\
\text { and establishing a career } \\
\text { (within or without the } \\
\text { family business) }\end{array}$ & $\begin{array}{l}\text { Post-parental transition; new } \\
\text { members joining the family } \\
\text { (both in-laws and } \\
\text { grandchildren); children } \\
\text { ultimately disclosing } \\
\text { whether working within the } \\
\text { family business or not }\end{array}$ & $\begin{array}{l}\text { Retirement; involuntary } \\
\text { retirement; death; } \\
\text { widowhood; relocation and } \\
\text { institutionalization }\end{array}$ \\
\hline $\begin{array}{l}\text { Family stress } \\
\text { (McCubbin et } \\
\text { al., 1980; } \\
\text { Mattessich and } \\
\text { Hill, 1987; } \\
\text { Laszloffy, } \\
\text { 2002) }\end{array}$ & $\begin{array}{l}\text { Transition to parenthood; } \\
\text { adolescence and parents' } \\
\text { problems of control and } \\
\text { independence }\end{array}$ & $\begin{array}{l}\text { Children making stronger } \\
\text { requests for freedom and } \\
\text { autonomy; } \\
\text { relationship readjustment; } \\
\text { problems of working } \\
\text { together (son's entry into } \\
\text { the business); training and } \\
\text { development of the new } \\
\text { generation }\end{array}$ & $\begin{array}{l}\text { Training and development } \\
\text { of the new generation; } \\
\text { reputation, prestige and non- } \\
\text { economic motivations } \\
\text { attached to the firm }\end{array}$ & $\begin{array}{l}\text { Caregiving responsibilities } \\
\text { of older family members; } \\
\text { problems } \\
\begin{array}{l}\text { together } \\
\text { struggle }\end{array} \\
\begin{array}{l}\text { overlaps) } \\
\text { ovd }\end{array}\end{array}$ \\
\hline $\begin{array}{l}\text { Family } \\
\text { developmental } \\
\text { task hierarchy } \\
\text { (Mattessich } \\
\text { and Hill, 1987) }\end{array}$ & $\begin{array}{l}\text { Physical maintenance; } \\
\text { reproduction of new group } \\
\text { members; socialization and } \\
\text { schooling of new members }\end{array}$ & $\begin{array}{l}\text { Socialization and training of } \\
\text { new members; morale } \\
\text { maintenance; acquisition of } \\
\text { members and launching }\end{array}$ & $\begin{array}{l}\text { Morale maintenance; social } \\
\text { control; acquisition of } \\
\text { members } \\
\text { spouses) and launching; } \\
\text { reproduction; socialization } \\
\text { of new members }\end{array}$ & $\begin{array}{l}\text { Physical maintenance; } \\
\text { socialization of new } \\
\text { members; transfer of power }\end{array}$ \\
\hline
\end{tabular}




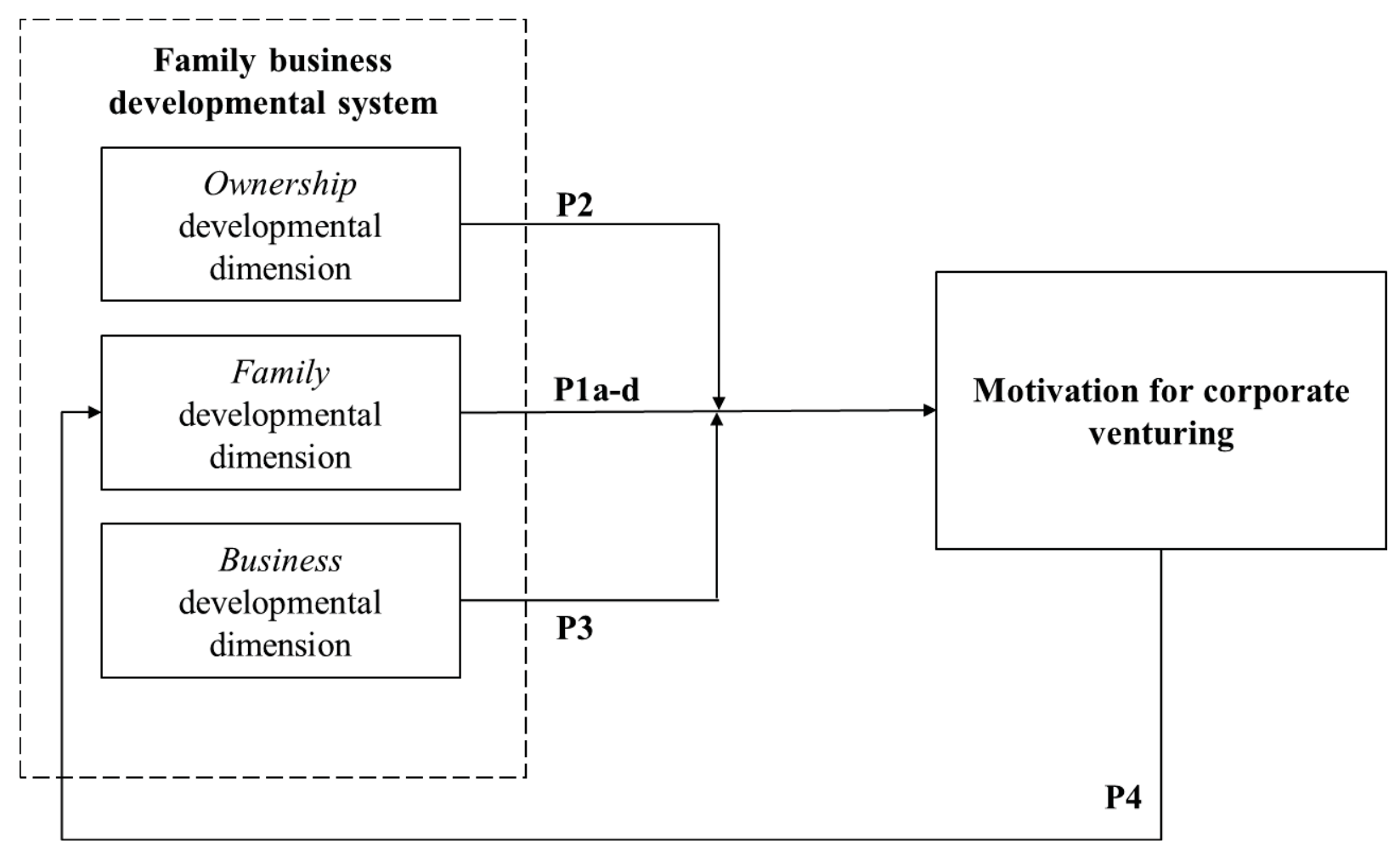

Figure 1. Conceptual framework

This article is protected by copyright. All rights reserved. 